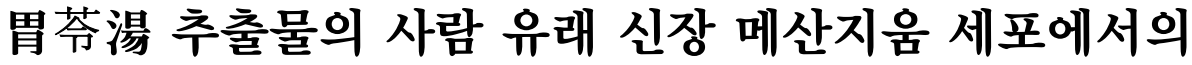 당뇨병성 신장 손상 개선 효과
}

\author{
윤정주 $^{1,2,3^{*}}$, 한병혁 ${ }^{1,2,3}$, 최은식 ${ }^{3}$, 남궁승 $^{1,2,3}$, 정다혜 ${ }^{1,2,3}$, 김혜윰 ${ }^{1,2,3}$, \\ 안유미 $^{1,2,3}$, 이윤정 ${ }^{1,2,3}$, 강대길 ${ }^{1,2,3}$, 이호섭 ${ }^{1,2,3 \#}$
}

1 : 원광대학교 한의과대학 생리학교실, $2:$ 원광대학교 한의학전문대학원, $3:$ 원광대학교 한방체액조절연구센터

\section{Wiryeongtang attenuates diabetic renal dysfunction in human renal mesangial cells}

\author{
Jung Joo Yoon ${ }^{1,2,3^{*}}$, Byung Hyuk Han ${ }^{1,2,3}$, Eun Sik Choi ${ }^{3}$, Seung NamGung ${ }^{1,2,3}$, \\ Da Hye Jeong ${ }^{1,2,3}$, Hye Yoom Kim ${ }^{1,2,3}$, You Mee Ahn ${ }^{1,2,3}$, Yun Jung Lee ${ }^{1,2,3}$, \\ Dae Gill Kang ${ }^{1,2,3}$, Ho Sub Lee ${ }^{1,2,3 \#}$
}

1 : College of Korean Medicine, 2 : Professional Graduate School of Korean Medicine,

3 : Hanbang Body-fluid Research Center, Wonkwang University

\begin{abstract}
Objectives : Diabetic nephropathy is one of the most common chronic complications of diabetes and a leading cause of end-stage renal failure in the world. Mesangial cell proliferation is known as the major pathologic features such as glomerulosclerosis and renal fibrosis. Wiryeongtang (WRT) is a well-known traditional herbal formula as therapeutic agents for chronic edema and dysuresia of renal homeostasis. In the present study, we investigated whether WRT inhibits high glucose (HG)-induced renal dysfunction by TGF- $\beta /$ Smads signal regulation in cultured mesangial cells.

Methods : Inhibitory effect of WRT (10-50 $\mathrm{m} / \mathrm{ml})$ on HG-stimulated mesangial cells proliferation and dysfunction were evaluated by $\left[{ }^{3} \mathrm{H}\right]$-thymidine incorporation, Western blot, and RT-qPCR.

Results : WRT significantly decreased HG-accelerated thymidine incorporation in human renal mesangial cell in a dose-dependent levels. WRT induced down-regulation of cyclins/CDKs and up-regulation of CDK inhibitor, p21waf1/cip1 and p27kip1 expression. In addition, HG enhanced expression of dysfunction biomarker such as collagen IV and CTGF, which was markedly attenuated by WRT. WRT decreased TGF- $\beta 1$ and Smad-2/Smad-4 expression, whereas increased Smad-7 expression under HG. Furthermore, WRT inhibited HG-induced inflammatory factors level such as ICAM-1 and $\mathrm{MCP}-1$ as well as $\mathrm{NF}-\kappa \mathrm{B}$ p65 nuclear translocation and intracellular ROS production.

Conclusions : These results suggested that WRT may alleviate mesangial proliferation and inflammation possibly involved in renal fibrotic process, further diabetic nephropathy through disturbing TGF- $\beta 1 /$ Smad signaling and $\mathrm{NF}-\kappa \mathrm{B} / \mathrm{ROS}$ pathway. Thus, WRT might prove to be effective in the treatment of renal dysfunction leading to diabetic nephropathy.
\end{abstract}

Key words : Wiryeongtang; diabetic nephropathy; mesangial cell; TGF- $\beta 1$; renal dysfunction

\footnotetext{
*Corresponding author : Ho Sub Lee, College of Korean Medicine, Wonkwang University

·Tel : +82-63-850-6841 · Fax : +82-63-850-7260 ·E-mail : host@wku.ac.kr

\#First author : Jung Joo Yoon, College of Korean Medicine, Wonkwang University

- Tel : +82-63-850-6447 · Fax : +82-63-850-7260 • E-mail : morality16@ hanmail.net

- Received : 19 July 2016 · Revised : 2 September 2016 · Accepted : 20 September 2016
} 


\section{I. 서 론}

최근 의학의 발달로 인한 당뇨병의 급성 합병증에 따른 사 망은 감소하였으나 당뇨병에 의한 만성 합병증에 속하는 대혈 관 및 미세 혈관 합병증 등은 오히려 증가하는 추세이다 ${ }^{1,2)}$. 특히 사구체의 미세 혈관 합병증 중 하나인 당뇨병성 신증은 말기 신부전증 (end stage renal failure; $\mathrm{ESRF}$ )의 가장 주 요한 원인으로 당뇨 합병증에 의한 사망률 중 가장 높은 빈도를 차지하는 질환이다 ${ }^{3)}$. 이러한 당뇨병성 신증의 일반적인 병리 학적 소견으로는 고혈당으로 인한 사구체와 세뇨관의 비후 및 메산지움 세포의 증식과 메산지움 기질의 축적이 나타나며, 이러한 현상들의 지속적인 진행으로 인해 사구체 경화증을 일 으켜 결국 신부전(renal failure)과 같은 신장 기능 장애가 유 발된다 ${ }^{4)}$.

Transforming growth factor $(\mathrm{TGF}-\beta)$ 는 세포외기질 (extracellular matrix ; ECM)의 합성을 촉진하여 섬유화를 유도하는 주요한 사이토카인으로 신장의 메산지움 및 신세뇨 관 세포에 분포하고 있으며, 당뇨병성 신증 발생에 있어 대표 적인 인자 중의 하나로 알려져 있다 ${ }^{5,6)}$. TGF- $\beta$ 는 $\mathrm{TGF}-\beta$ type I receptor (T $\beta \mathrm{RI}$ ) 및 TGF- $\beta$ type II receptor (T $\beta \mathrm{RI}$ I)와 결합하여 serine/threonine kinase를 활성화 시키고, 전사인자 역할을 하는 $\mathrm{Smad}-2, \mathrm{Smad}-3, \mathrm{Co}-\mathrm{Smad}-4$ complex를 형성하고, 핵으로 이동하여 섬유화 유도 기전을 활성화 시킨다 ${ }^{7,8)}$. 고혈당, 고혈압 등에 의해 $\mathrm{TGF}-\beta$ 의 발현 이 증가되며 세포외 기질인 fibronectin, 제 1 형 콜라겐, 제 4 형 콜라겐 등의 합성을 증가시켜 $\mathrm{ECM}$ 의 축적을 촉진한다. 사 구체 기저막의 주요 구성 성분이며 신장섬유화의 지표가 되는 것으로 알려진 collagen IV 역시 당뇨병에서 고혈당에 의해 그 합성이 증가하여 사구체 메산지움 영역내의 침착을 증가시 키는 주된 병리인자로 알려져 있다,10). 최근 사구체에서 $\mathrm{TGF}-\beta 1$ 및 collagen IV의 발현을 억제함으로써 신장의 섬 유화를 억제하여 사구체 경화 및 당뇨병성 신증 개선을 통해 만성 신부전을 예방하기 위한 연구가 많이 진행되고 있다.

최근 당뇨병성 신증의 진행에 Interleukin-1 ( $\mathrm{IL}-1$ ), $\mathrm{IL}-6, \mathrm{IL}-18$, tumor necrosis factor- $\alpha(\mathrm{TNF}-\alpha)$ 그리고 monocyte chemoattractant protein-1 $(\mathrm{MCP}-1)$ 등의 염 증성 cytokine이 관여하는 것으로 보고되고 있다 ${ }^{11)}$. 염증성 cytokine은 염증 반응을 나타내는 효과 이외에도 신장 조직 에 직접적인 영향을 미치기도 하는데, 다양한 연구에서 고포 도당으로 자극한 사구체 메산지움 세포에서 $\mathrm{MCP}-1$ 의 $\mathrm{mRNA}$ 발현과 그 단백 생산을 증가시킴이 관찰되었으며, CCR2(cysteine-cysteine chemokine receptor)와 결합을 통하여 직접적으로 fibronectin과 collagen IV의 생성을 유 도한다는 보고도 있다 ${ }^{12)}$. 염증반응에 관여 하는 것으로 알려진 중요한 전사인자 중 하나인 nuclear factor $\kappa \mathrm{B}(\mathrm{NF}-\kappa \mathrm{B})$ 가 활성화되면 tumor necrosis factor- $\alpha(\mathrm{TNF}-\alpha), \mathrm{IL}-1 \beta$, $\mathrm{TGF}-\beta 1$ 등을 증가시키고, 이는 다시 $\mathrm{NF}-\kappa \mathrm{B}$ 를 활성화시켜 당뇨병성 신증의 발생을 촉진시킨다 ${ }^{13,14)}$. 또한 산화성 스트레 스에 의하여 생성되는 reactive oxygen species (ROS)는 당 뇨 합병증과 밀접한 연관 인자로 만성적 고혈당 상태에서 $\mathrm{ROS}$ 의 생성은 증가되며, 과생산된 ROS는 세포막 지질의 peroxidation, 단백의 산화 그리고 DNA의 손상을 초래하는 등의 작용하게 된다. 이런 ROS에 의하여 활성화된 신호전달
체계는 신장 내에서 섬유화와 관련된 유전자의 전사를 증가시 키는 것으로 알려져 있다 ${ }^{15-17)}$. 따라서, 당뇨병성 신증으로의 이행 전인 신 염증 단계에서 산화적 스트레스를 감소시키고 염증 인자들의 조절은 당뇨의 증상을 완화시키는 것 뿐 아니 라 당뇨병성 신증의 예방에 필수적이라 할 수 있다.

胃苓湯은 平胃散과 五苓散의 합방을 기반으로 한 처방으로 감초, 계지, 대조, 백출, 생강, 저령, 적복령, 진피, 창출, 택 사, 후박, 백작약의 총 12 종의 약재로 구성된 처방으로 朱가 쓴「丹溪心法」에 수록된 방제이다 ${ }^{18)}$. 동의보감에서는 위를 조 화시키고 기를 화평하게 하는 방제로서 수재되어 있으며 예로 부터 脾胃에 寒과 濕이 병을 일으킨 것과 복통을 동반한 급, 만성설사와 대장염, 소변불리 등에 사용되었다 ${ }^{19)}$. 이러한 위 령탕은 高指血症, 신장염 등의 개선 효과가 있는 것으로 보고 되어 있으나 ${ }^{20)}$, 위령탕의 당뇨병성 신증에 대한 효과 및 그 조절기전에 대해서는 아직까지 없었다. 이에 본 연구에서는 위령탕이 고포도당에 의한 메산지움 세포의 $\mathrm{TGF}-\beta / \mathrm{Smad}$ 및 $\mathrm{NF}-\kappa \mathrm{B} / \mathrm{ROS}$ 억제 효과와 이에 의한 당뇨병성 신증 개선 에 대한 영향을 알아보고자 하였다.

\section{II . 재료 및 방법}

\section{1. 시료의 제조}

위령탕 (Herbarium voucher No. HBH262-01)을 분말 로 만들어 플라스크에 넣은 후, 증류수 $500 \mathrm{ml}$ 를 가하고 9 $5{ }^{\circ} \mathrm{C}$ 에서 6 시간 가열하여 환류 추출하였다. 여과지를 이용하 여 여과한 다음, 여과액을 Evaporator (EYELA, Japan)을 이용하여 감압 농축하고 농축액을 동결 건조하여 실험 시까지 냉동보관 하였다. 실험 시에는 위령탕 추출물을 pure distilled water를 이용하여 배지에 녹인 후, pore size $0.45 \mu \mathrm{m}$ 의 여 과지를 통과시킨 후 사용하였다. 위령탕은 감초 $1.875 \mathrm{~g}$, 계 지 $1.875 \mathrm{~g}$, 대조 $2 \mathrm{~g}$, 백작약 $3.75 \mathrm{~g}$, 백출 $3.75 \mathrm{~g}$, 생강 2 $\mathrm{g}$, 저령 $3.75 \mathrm{~g}$, 적복령 $3.75 \mathrm{~g}$, 진피 $3.75 \mathrm{~g}$, 창출 $3.75 \mathrm{~g}$, 택사 $3.75 \mathrm{~g}$, 후박 $3.75 \mathrm{~g}$ 으로 구성되어 있다. 여과된 추출 물은 농축 후 냉동 건조기를 이용하여 동결 건조시켜 수율 약 $17 \%(6.3 \mathrm{~g})$ 의 양을 획득하여 실험에 사용하였다 (Table1).

\begin{tabular}{|c|c|c|}
\hline Herbal Name & Scientific Name & Dose amount (g) \\
\hline 甘草 & Glycyrrhiza uralensis & 1.875 \\
\hline 桂枝 & Cinnamomum cassia & 1.875 \\
\hline 大柾 & Zizyphus jujuba var. inermis & 2 \\
\hline 白芶藥 & Paeonia albiflora Pallas var. trichocarpa & 3.75 \\
\hline 白尤 & Atractylodes macrocepha-la & 3.75 \\
\hline 生薑 & Zingiber officinale & 2 \\
\hline 猪苓 & Polyporus umbellatus & 3.75 \\
\hline 赤获苓 & Poria cocos & 3.75 \\
\hline 陳皮 & Citrus unshiu & 3.75 \\
\hline 荅术 & Atractylodes lancea & 3.75 \\
\hline 澤瀉 & Alisma orientalis & 3.75 \\
\hline \multirow[t]{2}{*}{ 厚朴 } & Magnolia officinalis & 3.75 \\
\hline & Total & 37.75 \\
\hline
\end{tabular}




\section{2. 메산지움 세포의 배양}

사람 유래 신장 메산지움 세포(HRMC)는 ScienceCell ${ }^{\mathrm{TM}}$ (ScienceCell Research Laboratories Inc., Carlsbad, CA) 로부터 구입하여 사용하였다. 메산지움 세포의 배양은 $10 \%$ 우태아혈청과 $100 \mu \mathrm{g} / \mathrm{ml}$ 의 penicillin을 첨가한 저농도 포도 당 $(100 \mathrm{mg} / \mathrm{ml})$ 함유 Dulbecco's modified Eagle's medium (DMEM; Gibco, Grand Island, NY)에서 $37^{\circ} \mathrm{C}, 5 \% \mathrm{CO}_{2}$ 세 포배양기를 이용하여 배양하였다. 배양액은 2 일 마다 바꿔주 었다. 본 연구에는 3 대째 계대배양 중인 메산지움 세포를 사 용하였다.

\section{3. $\left[{ }^{3} \mathrm{H}\right]$-thymidine incorporation을 이용한 메 산지움 세포 증식 평가}

메산지움 세포를 24 well 세포 배양용기에 각 well당 $5 \times 10^{4}$ 개의 세포가 되도록 분주하여 3 회 실험하였다. 이 세 포들을 $10 \%$ 우태아 혈청이 함유된 DMEM 배양액으로 72 시 간 배양한 후, 혈청배제 DMEM으로 24 시간 동안 배양하여 세포주기를 동일화하였다. 24 well 세포 배양용기에 각 well 당 $5 \times 10^{4}$ 개의 세포가 되도록 분주하여 3 회 실험하였다. 실 험이 종료되기 24 시간 전에 $\left[{ }^{3} \mathrm{H}\right]$-thymidine을 각 well에 1 $\mu \mathrm{Ci} / \mathrm{well}$ 의 농도로 첨가하였다. 실험이 종료되면 배지를 제거 하고 냉장보관한 인산완충액으로 2 회 세척한 후, $10 \%$ trichloro acetic acid (TCA)로 15 분간 실온에서 방치한 후 $0.1 \mathrm{~N} \mathrm{NaOH}$ 로 1 시간 방치하여 세포를 용해한후 $2 \mathrm{ml}$ scintillation cocktail에 넣고 beta-counter (TL 5000s, BeckmanInstruments Inc., Fullerton, CA)을 이용하여 총 방사능을 측정하였다.

\section{4. $\mathrm{RNA}$ 의 분리 및 $\mathrm{RT}-\mathrm{PCR}$ 분석}

메산지움 세포를 $10 \mathrm{~cm}^{2}$ culture dish에 세포수가 $1 \times 10^{6}$ cells/dish 농도가 되도록 분주하여 배양한 후 실험을 진행하 였다. RNA 분리는 TRIzol reagent (Invitrogen Co., Carlsbad, $\mathrm{CA}$ )를 이용하여 총 RNA를 추출하였으며, 그 total RNA로부터 mRNA를 역전사시켜 $\mathrm{cDNA}$ 를 합성하고, 표적유전자인 collagen IV, $\mathrm{TGF}-\beta 1$, 그리고 Smads mRNA 에 대한 PCR은 HiPi Plus 5X PCR master mix (ELPIS, Taejeon, Korea)을 이용하여 수행하였다. 중합효소 연쇄 반 응 조건은 $95{ }^{\circ} \mathrm{C}$ 에서 3 분간 변성시킨 후 $94^{\circ} \mathrm{C}$ 에서 30 초간 변성반응, $55^{\circ} \mathrm{C}$ 에서 30 초 결합반응, $72^{\circ} \mathrm{C}$ 에서 45 초간 35 cycles 반응시켰다. 증폭된 DNA $10 \mu \mathrm{L}$ 를 취해 $1.5 \%$ agarose gel에서 전기 영동하였다. mRNA의 발현양상은 house keeping gene인 GAPDH로 보정하였으며 각각의 primer는 Table 2 와 같다.

\section{5. $\mathrm{ROS}$ 생성 측정}

세포 내 $\mathrm{ROS}$ 의 생성 정도를 측정하기 위하여 2',7'dichlorofluorescein diacetate (CM- $\mathrm{H}_{2} \mathrm{DCFDA}$, Invitrogen) 형광염료를 이용하였다. 근접 빛이 차단된 96-well dish에
$1 \times 10^{4}$ cells을 각각 seeding 한 후, 세포가 약 $70 \%$ 가량 자 랐을 때 $0.5 \% \mathrm{FBS} \mathrm{DMEM}$ 배지로 배양해 주었다. 각 조건 별로 24 시간 동안 배양한 후 $1 \mathrm{X} \mathrm{PBS}$ 로 두 번 세척해 준 후 새로운 $1 \mathrm{X} \mathrm{PBS}$ 와 함께 final 농도가 $10 \mu \mathrm{M}$ 이 되도록 $\mathrm{CM}-\mathrm{H}_{2} \mathrm{DCFDA}$ 를 첨가하여 30 분간 반응시켰다. 반응 종료 후, fluorescence spectrofluorometer (F-2500, Hitachi, Tokyo, Japan)를 이용하여 $485 \mathrm{~nm}$ 와 $535 \mathrm{~nm}$ 에서 spectrofluorimetry 분석으로 축적된 ROS에 결합된 형광 $\mathrm{DCF}$ 를 측정하여 대조군에 대한 상대적인 수치로 나타내었다.

Table 2. Reverse transcriptase PCR primer sequences

\begin{tabular}{|c|c|c|}
\hline \multicolumn{2}{|c|}{ Marker } & \multirow{2}{*}{$\frac{\text { Primer sequence }}{\text { 5'-TGA GTG GCT GTC TTT TGA CG-3' }^{\prime}}$} \\
\hline पन 2 & sense & \\
\hline $1 G T-p 1$ & anti-sense & $5^{\prime}-$ ACT TCC AAC CCA GGT CCT TC-3 \\
\hline \multirow{2}{*}{ Collagen $\mathrm{IV}^{22)}$} & sense & $5^{\prime}-$ CTG GCA CAA AAG GGA CGA G-3' \\
\hline & anti-sense & $5^{\prime}-\mathrm{ACG}$ TGG CCG AGA ATT TCA CC-3 \\
\hline \multirow{2}{*}{ Smad $-2^{23)}$} & sense & 5'-AAG AAG TCA GCT GGT GGG T-3' \\
\hline & anti-sense & $5^{\prime}-$ GCC TGT TGT ATC CCA CTG A-3' \\
\hline \multirow{2}{*}{ Smad $-3^{24)}$} & sense & $5^{\prime}-$ CAG AAC GTC AAC ACC AAG T-3' \\
\hline & anti-sense & $5^{\prime}-$ ATG GAA TGG CTG TAG TCG T-3' \\
\hline \multirow{2}{*}{$\mathrm{GAPDH}^{25)}$} & sense & $5^{\prime}$-CGA GAA TGG GAA GCT TGT CAT C-3' \\
\hline & anti-sense & $5^{\prime}-$ CGG CCT CAC CCC ATT TG-3' \\
\hline
\end{tabular}

\section{6. 단백 추출 및 Western blot 분석}

위령탕과 고포도당이 처리된 세포를 $\mathrm{PBS}$ 로 2 회 세척하고, $\mathrm{RIPA}$ buffer를 넣고 $4{ }^{\circ} \mathrm{C}$ 에서 30 분간 반응 시킨 후, 13,000 $\mathrm{rpm}$ 으로 10 분간 원심 분리하여 단백질을 추출하였다. 단백질 정량은 Bradford (Bio-Rad)법을 이용하여 단백질의 동량을 $10 \%$ SDS-PAGE (sodium dodecyl sulfate-polyacrylamide gel electrophoresis)로 전기 영동하여 분리한 후 nitrocellulose membrane으로 transfer하였다. 비 특이적 antibody 결합을 방지하기 위해 membrane을 $5 \%$ skim milk가 함유된 Tris-buffered saline (TBS) 용액에 상온에서 1 시간 동안 blocking하였다. Blocking된 membrane을 1:1,000으로 희 석한 각 타겟 단백질의 1 차 antibody로 2 시간 이상 처리하 였다. 그 후 TBS-Tween 20으로 3 회 세척한 다음 $1: 2,000$ 으로 희석시킨 2 차 antibody를 상온에서 1 시간 반응시키고 TBS-tween 20으로 3회 세척한 후 ECL solution을 반응시 켜 발현 정도를 Chemidoc image analyzer (Bio-Rad, Hercules, CA)을 사용하여 측정 후 정량하였다.

\section{7. 핵과 세포질에서 단백질 분리}

위령탕과 고포도당이 처리된 세포를 $\mathrm{PBS}$ 로 2 회 세척한 후 세포를 모은 후 원심 분리하여 상층액을 제거 하였다. 이 세 포에 buffer A [10 mM HEPES-KOH, pH 7.9, $1.5 \mathrm{mM}$ $\mathrm{MgCl}_{2}, 10 \mathrm{mM} \mathrm{KCl}, 0.5 \mathrm{mM}$ dithiothreitol (DTT), 0.2 $\mathrm{mM}$ phenylmethylsulfonyl fluoride (PMSF), Nonidet $\mathrm{P}-40(\mathrm{NP}-40)$ ]를 넣어 15 초간 vortexing한 후 ice에서 15 분간 두었다. 그 후 $12,000 \mathrm{rpm}$ 에서 5 분간 원심 분리하여 
세포질의 단백질이 포함되어있는 상층액을 tube에 옮겨 -7 $0{ }^{\circ} \mathrm{C}$ 에서 보관하고, pellet에 buffer $\mathrm{B}$ [20 mM HEPES, pH 7.9, $25 \%$ glycerol, $0.42 \mathrm{M} \mathrm{NaCl}, 1.5 \mathrm{mM} \mathrm{MgCl}_{2}, 0.2$ mM EDTA, $0.5 \mathrm{mM}$ DTT, $0.2 \mathrm{mM}$ PMSF, protease inhibitor cocktail]을 넣고 10 초간 vortexing한 후 매 10 분마다 3회 vortexing 하였다. 그 후 $12,000 \mathrm{rpm}$ 에서 10 분 간 원심 분리하여 핵 단백질 부분을 포함하는 그 상층액을 새 로운 tube에 옮겨 $-70^{\circ} \mathrm{C}$ 에서 보관하였다.

\section{8. 통계분석}

실험군 간의 유의성은 Systat사의 SigmaPlot 10.0 을 이용 하여 실험 결과를 Student' $\mathrm{s}$ t-test를 통하여 $\mathrm{p}$ 값이 0.05 이하인 경우 유의한 차이로 판정하였고, 실험 치의 표현은 mean \pm S.E.로 하였다.

\section{III. 결 과}

\section{1. 위령탕의 메산지움 세포 증식 억제 효과}

위령탕의 메산지움 세포 증식에 대한 영향을 관찰하기 위 해 $\left[{ }^{3} \mathrm{H}\right]$-thymidine 의 결합 정도를 관찰하였다. 그 결과, 고 포도당은 사람 유래 신장 메산지움 세포의 증식을 대조군에 비해 유의하게 증가시켰으나, 위령탕 투여는 농도에 비례하여 $\left[{ }^{3} \mathrm{H}\right]$-thymidine 의 결합 정도가 감소됨을 알 수 있었다. 특 히 $20 \mu \mathrm{g} / \mathrm{ml}$ 과 $50 \mu \mathrm{g} / \mathrm{ml}$ 의 농도로 위령탕을 전 처리 했을 때 유의한 감소를 나타내었다 (Fig. $1, \mathrm{p}\langle 0.05, \mathrm{p}<0.01$ ).

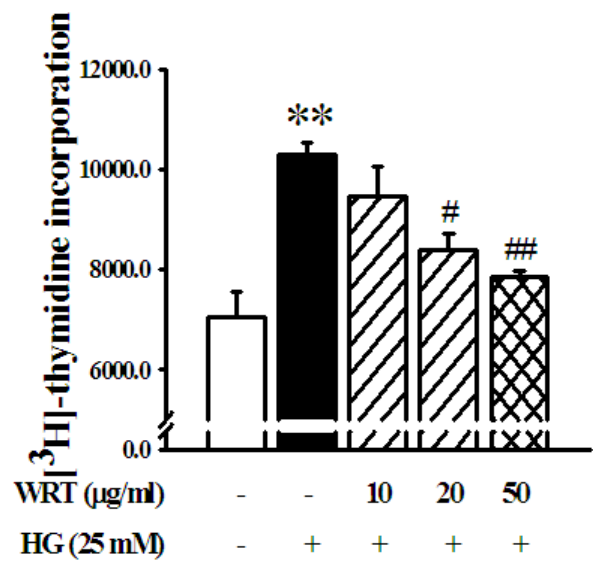

Figure 1. Effects of wiryeong-tang on HG-induced cultured renal mesangial cell proliferation. Mesangial cells were seeded into the 24-well plates. After confluence, the cells incubated for $24 \mathrm{~h}$ with or without $\mathrm{HG}$ and various concentrations of wiryeong-tang, and then pulse-labeled with $\left[{ }^{3} \mathrm{H}\right]$-thymidine for $24 \mathrm{~h}$. Results are expressed as the mean \pm S.E. from three independent experiments. ${ }^{* *} \mathrm{p}<0.01$ vs. control; \#p<0.05, \#\#p<0.01 vs. $\mathrm{HG}$ alone.

또한, 신장 메산지움 세포에 대한 위령탕의 항-증식작용이 세포주기 조절 인자들의 조절에 의한 것인가를 확인하기 위해 Western blot 법을 이용하였다. 세포의 성장을 유도하는 단 백질인 $\mathrm{CDK} 2, \mathrm{CDK} 4$, cyclinD1, 그리고 cyclinE의 단백질
발현 변화는 대조군에 비해 고포도당을 처리한 군에서의 눈에 띄는 증가를 보였으나, 위령탕을 전 처리한 군에서는 세포주 기 조절 단백질들의 발현이 유의하게 감소하는 것을 보였다. 위령탕은 cyclin 계열의 세포성장을 촉진하는 단백질의 발현 이 감소하는 반면, 세포성장을 저해하는 단백질인 $\mathrm{p} 21$ 과 $\mathrm{p} 27$ 의 발현은 증가됨을 나타내었다 (Fig. 2).

A.

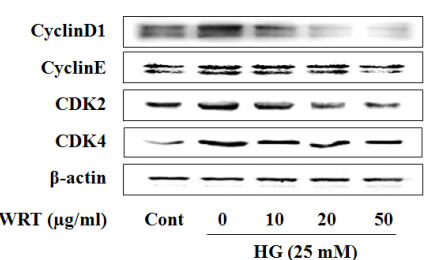

B.
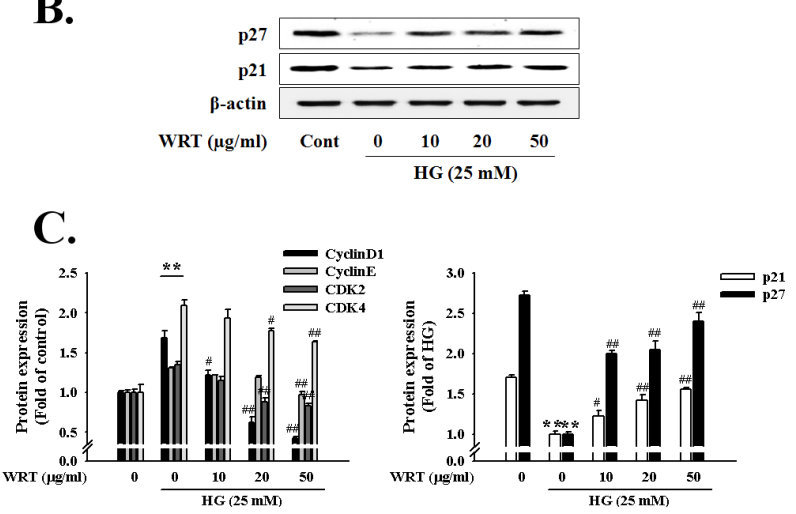

Figure 2. Effects of wiryeong-tang on HG-induced cell cycle regulator protein expression. Cells were stimulated with $\mathrm{HG}$ in the presence or absence of indicated concentration of wiryeong-tang at $24 \mathrm{~h}$ and Western blot analysis was performed with antibodies specific for Cyclin D1/E, CDK2/4, p21 wart/cip1, and $\mathrm{p} 27^{\mathrm{kip} 1}$, respectively. Each electrophoretogram is representative of the results from five independent experiments.

\section{2. 위령탕의 신장 손상 개선 효과}

위령탕 추출물에 의한 신장 손상에 대한 개선 효과를 확인 하고자 다양한 자극에 의한 세포외기질 단백의 생산의 최종 매개인자로서 섬유화의 지표로 인식되고 있는 collagen IV 및 $\mathrm{TGF}-\beta 1$ 단백질 발현 정도를 확인하였다. 그 결과, 대조 군에 비해 collagen IV 과 $\mathrm{TGF}-\beta 1$ 발현 정도가 눈에 띄는 증가를 보였으며, 위령탕 추출물에 의해 감소되었다 (Fig. $3 \mathrm{~A})$. 또한 본 $\mathrm{TGF}-\beta 1$ 의 하위신호 중 잘 알려진 $\mathrm{Smad}$ 의 단 백질 발현에 대한 위령탕의 영향을 실험한 결과에서, 고포도 당에 의해 증가된 $\mathrm{Smad}-2$ 와 $\mathrm{Smad}-3$ 의 인산화 정도가 위 령탕에 의해 감소되는 것을 확인할 수 있었다. 또한 $\mathrm{CO}-$ $\mathrm{Smad}$ 인 $\mathrm{Smad} 4$ 의 단백질 발현 역시 위령탕에 의해 억제됨을 볼 수 있었다. 그러나 inhibitory-Smad인 Smad-7는 고포 도당에 의해 감소하였으며, 위령탕에 의해 회복됨을 보였다 (Fig. 3B). 이와 같은 신장 섬유화 관련 인자들의 단백질 발 현 변화는 $\mathrm{mRNA}$ 수준에서 측정한 결과와 유사하게 나타났 다 (Fig. 4). 
A.

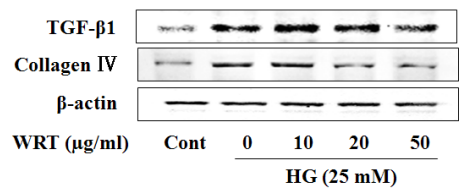

B.

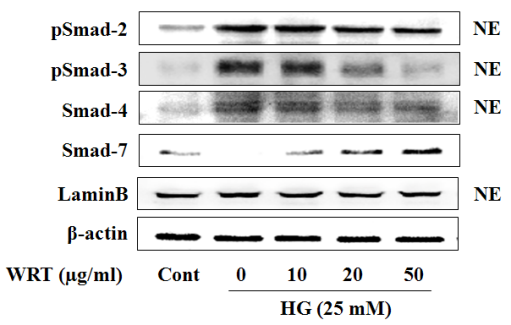

C.

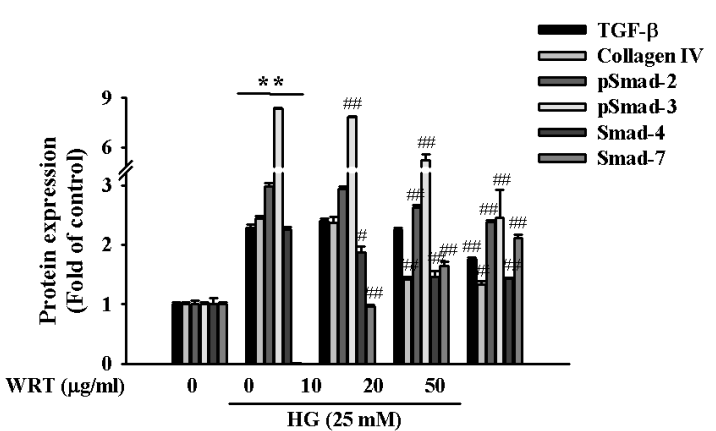

Figure 3. Effect of wiryeong-tang on TGF- $\beta 1$, collagen IV, and Smads protein expression under HG condition. Cells were stimulated with $H G$ in the presence or absence of indicated concentration of wiryeong-tang at $24 \mathrm{~h}$ and Western blot analysis was performed with antibodies specific for TGF- $\beta 1$, collagen IV, and Smads (pSmad-2, pSmad-3, Smad-4 and Smad-7), respectively. $\beta$ -actin was used as the internal standard in each sample. Each electrophoretogram is representative of the results from five independent experiments.

\section{3. 위령탕의 면역세포 침윤관련 인자들에 대한 억제효과}

Western blot 법을 통하여 메산 지움 세포 내 ICAM-1과 $\mathrm{MCP}-1$ 의 발현양상을 조사해 본 결과, 고포도당을 처리하였 을 때 ICAM-1의 발현이 크게 증가하였고, 증가된 ICAM-1 은 WRT의 처리 농도 의존적으로 감소되었다. 특히 $50 \mu \mathrm{g} / \mathrm{ml}$ 의 농도에서는 대조군 수준 정도의 발현 억제 효과를 보였다. $\mathrm{MCP}-1$ 의 경우도 고포도당를 처리했을 때, 발현이 크게 증가 한 반면, 위령탕에 의해서는 $50 \mu \mathrm{g} / \mathrm{ml}$ 의 농도에서 아주 높은 발현 억제 효과를 보였다 (Fig. $5 \mathrm{~A}$ ). 또한, 염증 반응 조절에 관여하는 전사인자로 알려진 $\mathrm{NF}-\kappa \mathrm{B}$ 의 발현에 대한 위령탕의 영향을 알아보기 위하여 핵과 세포질 단백질을 각각 추출하여 그 발현 변화를 측정하였다. 그 결과, 고포도당을 단독 처리 했을 때 핵 부분의 $\mathrm{NF}-\kappa \mathrm{B}$ p 65 의 발현이 유의성 있게 증가하 였고, 위령탕 추출물을 전 처리 하였을 때는 핵 내 $\mathrm{NF}-\kappa \mathrm{B}$ $\mathrm{p} 65$ 가 농도 의존적으로 억제되었다 (Fig. 5B).
A.

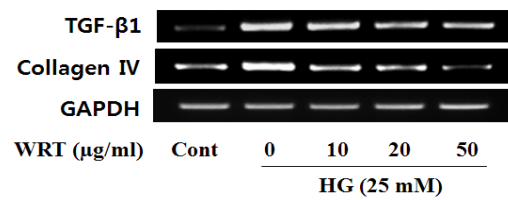

B.

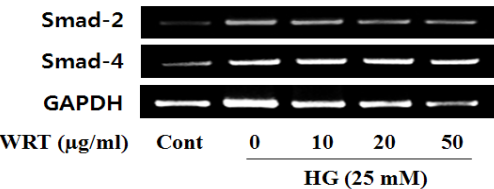

C.

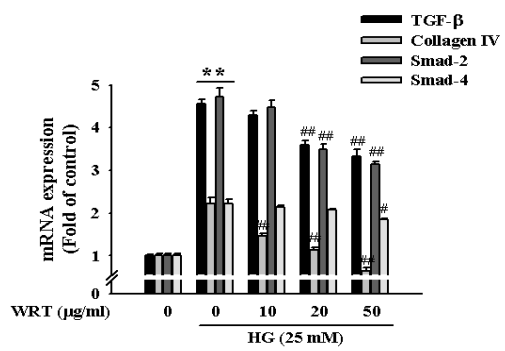

Figure 4. Effect of wiryeong-tang on TGF- $\beta$ 1, collagen IV, and Smads mRNA levels. Cells were treated with $\mathrm{HG}(25 \mathrm{mM})$ for 24 $\mathrm{h}$ in the absence or pre-treatment of wiryeong-tang $(10,20$, and $50 \mu \mathrm{g} / \mathrm{ml}$ ) for $30 \mathrm{~min}$ and prepared to perform RT-PCR analysis. GAPDH was used as the internal standard in each sample. Each electrophoretogram is representative of the results from five independent experiments.

A.

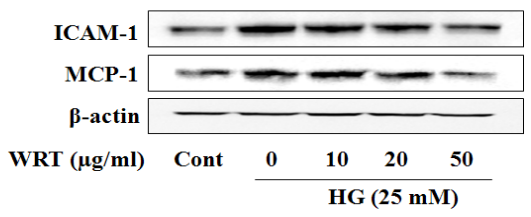

B.

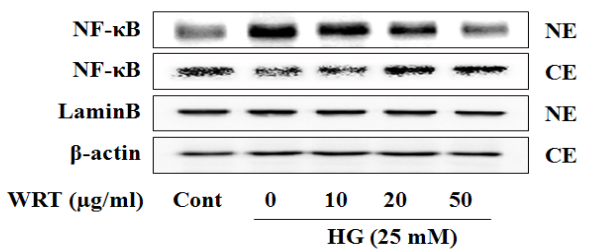

C.

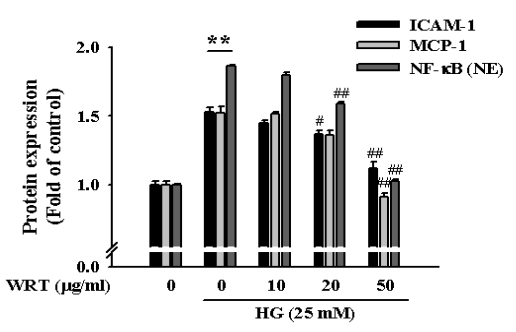

Figure 5. Effect of wiryeong-tang on $\mathrm{HG}$-induced renal pro-inflammatory. Cells were treated with $\mathrm{HG}(25 \mathrm{mM})$ for $24 \mathrm{~h}$ in the absence or pre-treatment of wiryeong-tang for $30 \mathrm{~min}$. (A) ICAM-1 and MCP-1 expression performed by western blot. (B) Effect of wiryeong-tang on blockade of nuclear translocation of $\mathrm{NF}-\kappa \mathrm{B}$. Confluent cells were incubated with $10-50 \mu \mathrm{g} / \mathrm{ml}$ wiryeong-tang for $2 \mathrm{~h}$ under the conditions of $\mathrm{HG}$. For Western blot analysis with a primary antibody against NF- $\kappa \mathrm{B}$, and nuclear fractions were obtained. $\beta$-actin and LaminB were used as an internal control. 


\section{ROS 생성에 대한 위령탕의 억제효과}

세포의 사멸 및 증식에 있어서 중요한 역할을 하는 것으로 알려진 ROS의 생성에 대한 위령탕의 영향을 알아보기 위해 $\mathrm{CM}-\mathrm{H}_{2} \mathrm{DCFDA}$ 염색을 통해 세포 내의 ROS 발현을 측정하 였다. 그 결과, 고포도당에 의해 증가된 $\mathrm{ROS}$ 의 생성 정도는 위령탕에 의해 농도-의존적인 감소를 보여주었다. 특히, 50 $\mu \mathrm{g} / \mathrm{ml}$ 의 농도로 위령탕을 전 처리한 군에서는 유의성 있는 차이를 보여 주었다 (Fig. 6, p<0.05).

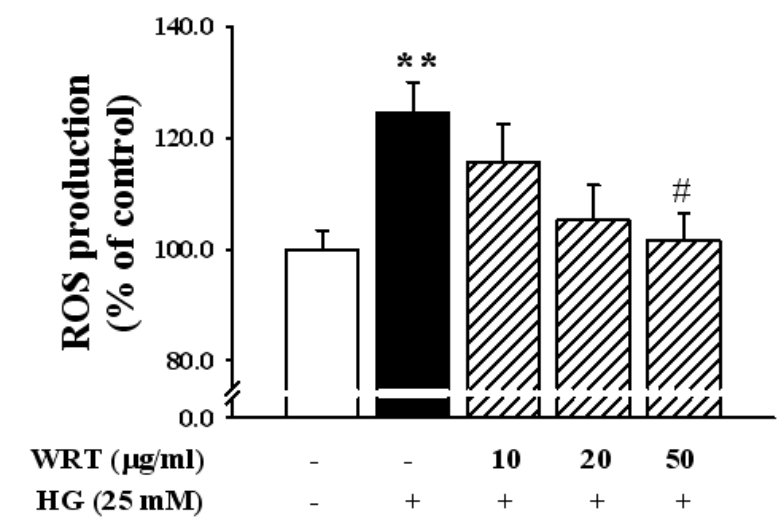

Figure 6. Effects of wiryeong-tang on $\mathrm{HG}$-induced intracellular ROS production. Renal mesangial cells were treated with HG for $24 \mathrm{~h}$ in the absence or pre-treatment of wiryeong-tang $(10,20$, $50 \mu \mathrm{g} / \mathrm{ml}$ ) for $30 \mathrm{~min}$ and then treated with CM-H2DCFDA. Bar represents the mean \pm S.E. of more than three independent experiments. ${ }^{* *} \mathrm{p}<0.01$ vs. control; \#p<0.05 vs. HG alone.

\section{IV. 고 찰}

위령탕은 화위건비의 평위산에 수습의 기본방제인 오령산 을 합방하여 脾胃傷冷, 水穀不分, 泄瀉不止로 水濕內停, 小便 不利에 사용되어 왔다 ${ }^{26)}$. 그러나 위령탕의 신장 손상에 대한 개선 효과에 대해 과학적인 증명이 이루어지지 않았다. 이에 본 연구에서는 고포도당에 의해 유도된 사람 유래 신장의 사 구체 메산지움 세포에서 위령탕이 사구체 세포의 증식 및 섬 유화를 효율적으로 억제하는지에 대한 효과 검증 및 그 기전 에 대해 알아보았다.

먼저, 고포도당에 의한 메산지움 세포의 증식 및 세포주기 조절 단백질의 발현 변화를 조사하여 당뇨병성 신증의 발생과 진행에 대하여 위령탕이 가지는 세포병리학적 역할과 의의를 규명하였다. $\left[{ }^{3} \mathrm{H}\right]$-thymidine assay를 통해 메산지움 증식에 대한 위령탕의 영향을 확인한 결과에서 고포도당에 의해 증가 된 $\left[{ }^{3} \mathrm{H}\right]$-thymidine 의 결합 정도가 위령탕 전처리에 의해 유 의적으로 감소함을 보였다. 위령탕은 또한 세포 주기 조절 인 자인 $\mathrm{CDK} 2 / 4$ 와 cyclin $\mathrm{D} 1 / \mathrm{E}$ 의 발현은 억제시켰으며 만대 로 $\mathrm{CDK}$ 억제제인 $\mathrm{p} 21$ 과 $\mathrm{p} 27$ 의 발현은 대조군 수준으로 회복 시키는 것으로 나타났다. 이는 위령탕이 세포주기 관여 인자 들의 조절을 통해 고포도당에 의해 유도되는 메산지움 세포의 과도한 증식을 억제 할 것으로 보여진다.

당뇨병성 신증에서 다양한 cytokine이나 성장인자들이 신 장의 사구체 세포들을 비롯한 세뇨관 간질조직의 염증발현, 세포증식 및 경화과정의 병태생리학적 기전에서 중요한 역할
을 담당하는 매개물질임이 규명되었는데, 이중 $\mathrm{TGF}-\beta$ 는 진 행성 신손상에 가장 중요한 역할을 한다고 밝혀져 있다. 만성 신질환의 진행에서 $\mathrm{TGF}-\beta$ 은 collagen IV와 같은 $\mathrm{ECM}$ 의 형 성을 촉진시켜 이들 물질의 과다축적으로 인한 사구체 비후와 사구체 경화 및 전체적인 신섬유화를 촉진하는 것으로 알려져 있다 ${ }^{27-29)}$. 이에 본 연구에서 고포도당에 의해 유발되는 초기 당뇨병성 신장 손상에 대한 위령탕의 영향에 대해 실험하였 다. 그 결과, 신장 메산지움 세포에서 고농도의 포도당은 $\mathrm{TGF}-\beta$ 의 단백질 발현 뿐 만 아니라 mRNA 수준에서의 발 현 역시 증가함이 나타났으며 이는 위령탕에 의해서 억제됨을 보였다. Smads의 발현 역시 위령탕에 의해 억제됨을 보였다. 또한 위령탕은 메산지움 팽창과 세포외 기질의 축적을 매개하 는 주된 병리인자인 collagen IV의 축적을 감소시키는데 효 과를 가지는 것으로 나타났다. 이를 통해 위령탕이 고포도당 에 의해 유도되는 신장 손상을 개선하는데 효과를 가지며 이 는 TGF- $\beta / \mathrm{Smad}$ 경로 조절을 통한 사구체 메산지움에서의 collagen IV의 축적을 감소시키며 결과적으로 사구체 세포외 기질의 축적을 억제함으로써 신장의 섬유화를 억제함에 대한 가능성을 확인한 것으로 사료된다. 이는 최근 사구체에서 $\mathrm{TGF}-\beta 1$ 의 발현을 억제함으로써 신장의 섬유화를 억제하여 사구체 경화 및 당뇨병성 신증 개선을 통해 만성 신부전을 예 방할 것이라는 많은 연구들과 일치한다 ${ }^{30)}$.

최근 당뇨병성 신증의 진행에 염증성 cytokine이 관여하는 것으로 보고되고 있다. 다양한 연구에서 고포도당으로 자극한 사구체 메산지움 세포에서 $\mathrm{MCP}-1$ 의 mRNA 발현과 그 단백 생산을 증가시킴이 관찰되었으며, 뿐만 아니라 fibronectin과 collagen IV의 생성을 시킨다는 보고도 있다 ${ }^{31)}$. 또한 염증반 응 조절 등에 관여 하는 전사인자로 알려진 $\mathrm{NF}-\kappa \mathrm{B}$ 가 활성화 되면 당뇨병성 신증의 발생을 촉진시킨다고 알려져 있으며 ${ }^{32)}$, 산화성 스트레스에 의하여 생성되는 ROS는 당뇨 합병증에 밀접하게 관여하며 ROS에 의해 활성화된 신호전달 체계는 신장 내에서 섬유화와 관련된 유전자의 전사를 증가시키는 것 으로 알려져 있다 ${ }^{33)}$. 또한 실험적 당뇨 동물 모델에서 다양한 항산화제 투여로 인하여 당뇨병성 신증의 진행이 억제되었다 는 여러 연구 결과들은 산화성 스트레스가 당뇨병성 신증의 진행에 중요한 요소임을 뒷받침하고 있다 ${ }^{34)}$. 따라서, 초기 당 뇨병성 신증으로의 이행 전인 염증 단계에서 염증인자 및 $\mathrm{ROS}$ 의 감소는 당뇨병성 신증의 예방에 필수적이라 할 수 있 다. 본 연구에서도 이를 확인하기 위해 $\mathrm{ICAM}-1, \mathrm{MCP}-1$ 그 리고 $\mathrm{NF}-\kappa \mathrm{B}$ p 65 의 발현 변화에 대한 위령탕의 영향을 연구 하였다. 그 결과, 고포도당에 의해 염증 관여 인자들의 단백 질 발현 뿐 만 아니라 $\mathrm{NF}-\kappa \mathrm{B}$ p 65 의 핵에서의 발현 역시 현 저한 증가를 보였으며 이를 위령탕이 억제시킴이 나타났다. 또한 위령탕은 ROS의 생성 정도 역시 감소시키는 것으로 나 타났다. 이를 통해 위령탕이 염증 관여 인자들의 발현 억제와 산화적 스트레스의 감소를 통해 pro-inflammatory 반응을 개선하는데 효과를 가지며 이는 결과적으로 당뇨병성 신증으 로의 진행을 억제하는데 영향을 미칠 것으로 사료된다.

이상의 결과에서 위령탕은 신기능 보호효과와 사구체 메산 지움 세포의 증식과 경화성 변화를 억제하는 것으로 나타났으 며, 이는 위령탕이 TGF- $\beta / \mathrm{Smad}$ 경로 억제를 통한 신장 손 상 개선으로 인한 collagen $\mathrm{IV}$ 축적 억제와 염증 관여 인자 
들의 발현 감소가 주요 작용 기전으로 관여하는 것으로 보인다. 따라서 본 연구를 통해 위령탕이 메산지움 세포에서의 신장 손상 및 pro-inflammatory 반응 개선을 통해 초기 당뇨병 성 신증으로의 진행에 있어 보호 효과를 가짐을 알 수 있었으 며, 향후 임상적 효능 및 안전성 검증을 위한 추가연구를 통 해 부작용이 거의 없는 초기 당뇨병성 신증 치료제로서의 가 능성을 가질 것으로 사료된다.

\section{$\mathrm{V}$. 결 론}

위령탕 추출물이 사람 신장 메산지움 세포에서 고포도당으로 유발된 신장 사구체 세포의 증식 및 신장 손상 개선 효과를 조 사하였으며, 다음과 같은 결론을 얻었다.

1. 위령탕 추출물은 고포도당에 의해서 유발된 신장 메산 지움 세포의 증식을 $\mathrm{CDK} / \mathrm{cyclin}$ 의 세포주기 조절 인자 들의 조절을 통해 유의하게 억제시켰다.

2. 위령탕 추출물은 고포도당에 의한 신장 손상에 대해 섬 유화 유도 인자인 collagen IV 억제 및 $\mathrm{TGF}-\beta / \mathrm{Smad}$ 경로 조절을 통해서 이를 유의하게 개선시켰다.

3. 위령탕 추출물은 신장 메산지움 세포에서 고포도당에 의해 유도된 초기 염증 인자들 (ICAM-1 및 $\mathrm{MCP}-1$ ) 의 발현을 억제하였다.

4. 위령탕 추출물은 신장 메산지움 세포에서 고포도당에 의해 유도된 $\mathrm{NF}-\kappa \mathrm{B}$ 의 핵에서의 발현 증가를 억제하였다.

5. 위령탕 추출물은 신장 메산지움 세포에서 고포도당에 의해 유도된 ROS 생성 증가를 억제하였다.

따라서, 위령탕 추출물은 고포도당에 의해 유발된 신장 메 산지움 세포의 증식, 신-손상, 그리고 초기 염증반응에 대한 억제 효과를 가지는 것으로 확인 되었으며, 이는 나아가 당뇨 병성 신증을 개선하는 데 있어 좋은 치료 방향이 될 것으로 사 료된다.

\section{감사의 글}

본 연구는 2015학년도 원광대학교 교비지원에 의해서 수 행되었으며 이에 감사드립니다.

\section{참고문헌}

1. Kim YS, Lee BC, Ahn SY, Doo HK, Ahn YM. The effects of Salvia Miltiorrhiza on renal function and histopathological changes in streptozotocin-induced diabetic nephropathy rat model. Korean J Orient Int
Med. 2008 ; 29(3) : 787-99.

2. Wei M, Ong L, Smith MT, Ross FB, Schmid K, Hoey AJ, Burstow D, Brown L. The StreptozotocinDiabetic Rat as a Model of the Chronic Complications of Human Diabetes. Heart Lung \& Circulation. 2003 ; 12(1) : 44-50.

3. Locatelli F, Pozzoni P, Del Vecchio L. Renal replacement therapy in patients with diabetes and end-stage renal disease. J Am Soc Nephrol. 2004 ; 15 : S25-9.

4. Fioretto P, Mauer M. Histopathology of diabetic nephropathy. Semin Nephrol. 2007 ; 27 : 195-207.

5. Flaumenhaft R, Abe M, Migntti P, Rifkin DB. Basic fibroblast growth factor-induced activation of latent transforming growth factor in endothelial cells: regulation of plasminogen activator activity. M $\mathrm{J}$ Cell Biol. 1992 ; 118 : 901-9.

6. Leask A. Abraham DJ. TGF-beta signaling and the fibrotic response. FASEB J. 2004 ; 18 : 816-27.

7. Attisano L, Wrana JL. Signal transduction by the TGF-beta superfamily. Science. 2002 ; 296 : 1646-7.

8. Meng XM, Huang XR, Chung AC, Qin W, Shao X, Igarashi P, Ju W, Bottinger EP, Lan HY. Smad2 protects against TGF-beta/Smad3-mediated renal fibrosis. J Am Soc Nephrol. 2010 ; 21(9) : $1477-87$

9. Kotajima N, Kimura T, Kand T, Obata K, Kuwabara A, Fukumura Y, Kobayashi I. Type IV collagen as an early marker for diabetic nephropathy in non-insulin-dependent diabetes mellitus. Journal of Diabetes and its Complications. 2000 ; 14 : $13-7$.

10. Zeisberg M, Ericksen MB, Hamano Y, Neilson EG, Ziyadeh F, Kalluri R. Differential expression of type IV collagen isoforms in rat glomerular endothelial and mesangial cells. Biochemical and Biophysical Research Communications. 2002 ; 295 : 401-7.

11. Ruef C, Kashgarian M, Coleman DL. Mesangial cell-matrix interactions: effects on mesangial cell growth and cytokine secretion. Am J Pathol. 1992 ; 141 : 429-39.

12. Park J, Ryu DR, Li JJ, Jung DS, Kwak SJ, Lee $\mathrm{SH}$, Yoo TH, Han SH, Lee JE, Kim DK, Moon SJ, Kim K, Han DS, Kang SW. MCP-1/CCR2 system is involved in high glucose-induced fibronectin and type IV collagen expression in cultured mesangial cells. Am J Physiol Renal Physiol. 2008 ; 295 : F749-57.

13. Kim IJ, Kim BW, Ha SW, Kim DW, Kim YK, Kim TH, Park JY, Yu HJ, Lee MK, Lee IK, Cha BY. 
Hyperglycemia and oxidative stress. Biology Research Information Center. 2003 ; 5(6) : 1-7.

14. Lee H, Yu MR, Yang Y, Jiang Z, Ha H. Reactive oxygen speciesregulated signaling pathways in diabetic nephropathy. J Am Soc Nephrol. 2003 ; 14(8) : 241-5.

15. Brownlee M. Biochemistry and molecular cell biology of diabetic complications. Nature. 2001 ; $414: 813-20$.

16. Nishikawa T, Edelstein D, Du XL, Yamagishi S, Matsumura T, Kaneda Y, Yorek MA, Beebe D, Oates PJ, Hammes HP, Giardino I, Brownlee M. Normalizing mitochondrial superoxide production blocks three pathways of hyperglycaemic damage. Nature. 2000 ; 404 : 787-90.

17. Phillips AO. The role of renal proximal tubular cells in diabetic nephropathy. Curr Diab Rep. 2003 ; $3: 491-6$.

18. Joo DG. Dangyesimbeopbuyeo. Seoul. 1982 ; 289.

19. Yun GY. Oriental Herbal Formula Science. Seoul, Publisher myeongbo. 1985 ; 198-204.

20. Jang HJ, Shin GC, Lee WC. Effect of Wiryeongtang on Triton WR-1339-induced hyperlipidemia rat. J of Oriental Chr Dis. 1998 ; 4(1) : 98-121.

21. Lei C, Zhou X, Pang Y, Mao Y, Lu X, et al. TGF$\beta$ signalling prevents pancreatic beta cell death after proliferation. Cell Prolif. 2015 ; 48 : 356-62.

22. Jeanne M, Jorgensen J, Gould DB. Molecular and Genetic Analyses of Collagen Type IV Mutant Mouse Models of Spontaneous Intracerebral Hemorrhage Identify Mechanisms for Stroke Prevention. Circulation. 2015 ; 131 : 1555-65.

23. Wu Q, Fukuda K, Weinstein M, Graff JM, Saga Y. SMAD2 and p38 signaling pathways act in concert to determine XY primordial germ cell fate in mice. Development. $2015 ; 142$ : 575-86.

24. Qu X, Li X, Zheng Y, Ren Y, Puelles VG, et al. Regulation of renal fibrosis by Smad3 Thr388 phosphorylation. Am J Pathol. 2014 ; 184 : 944-52.

25. Yoon JJ, Lee YJ, Lee SM, Kang DG, Lee HS. Oryeongsan suppressed high glucose-induced mesangial fibrosis. BMC Complement Altern Med. 2015 ; doi: 10.1186/s12906-015-0542-6.

26. SiSuDoMyeong. Clinical Applications New Herbal Prescription Commentary. Health news. 1985 ; 628.

27. Lee BC, Ahn YM, Doo HK, Ahn SY. The Anti-Proliferation Effects and Its Mechanism of Bupleurum falcatum on Human Mesangial Cell. Korean J Orient Int Med. 2004 ; 25(4) : 9-17.

28. Viklicky O, Matl I, Voska L, Bohmova R, Jaresova
M, Lacha J, Lodererova A, Striz I, Teplan V, Vitko S. TGF- $\beta 1$ Expression and Chronic Allograft Nephropathy in Protocol Kidney Graft Biopsy. Physiological reaserch. 2006 ; 52 : 353-60.

29. Goumenos DS, Kalliakmani P, Tsakas S, Sotsiou F, Vlachojannis JG. Urinary transforming growth factor-beta 1 as a marker of response to immunosuppressive treatment, in patients with crescentic nephritis. BMC Nephrology. 2005 ; $6(16): 1-7$.

30. Kim HY, Jang JH, Han SM, Ahn KS, Park SB, Kim HCl, Park KK. Expression of Transforming Growth Factor-beta1 Spontaneously Developed Diabetic Rats. Korean J Nephol. 2003 ; 22(2) : 165-73.

31. Park J, Ryu DR, Li JJ, Jung DS, Kwak SJ, Lee $\mathrm{SH}$, Yoo TH, Han SH, Lee JE, Kim DK, Moon SJ, Kim K, Han DS, Kang SW. MCP-1/CCR2 system is involved in high glucose-induced fibronectin and type IV collagen expression in cultured mesangial cells. Am J Physiol Renal Physiol. 2008 ; 295 : F749-57.

32. Lee FT, Cao Z, Long DM, Panagiotopoulos S, Jerums G, Cooper ME, Forbes JM. Interactions between angiotensin II and NF-kappaB-dependent pathways in modulating macrophage infiltration in experimental diabetic nephropathy. J Am Soc Nephrol. $2004 ； 15$ : 2139-51.

33. Phillips AO. The role of renal proximal tubular cells in diabetic nephropathy. Curr Diab Rep. 2003 ; $3: 491-6$.

34. Koo JR, Ni Z, Oviesi F, Vaziri ND. Antioxidant therapy potentiates antihypertensive action of insulin in diabetic rats. Clin Exp Hypertens. 2002 ; $24: 333-44$ 